\title{
ANALISIS SUMBER DAN PERUBAHAN ANGGARAN PADA BADAN PENGELOLA KEUANGAN DAERAH (BPKD) PROVINSI SULAWESI SELATAN
}

\author{
Nasrullah \\ nasrullah@unismuh.ac.id \\ Fakultas Ekonomi dan Bisnis \\ Universitas Muhammadiyah Makassar \\ Abdul Muttalib \\ abdulmuttalib@unismuh.ac.id \\ Fakultas Ekonomi dan Bisnis \\ Universitas Muhammadiyah Makassar \\ Hasdiati Latif \\ hasdiatilatif@gmail.com \\ Fakultas Ekonomi dan Bisnis \\ Universitas Muhammadiyah Makassar
}

\begin{abstract}
This study aims to determine the Analysis of Sources and Budget Changes at the Regional Finance Management Agency (BPKD) of South Sulawesi Province. This type of research is a quantitative descriptive approach, the data processed are budget changes in the Regional Financial Management Agency of South Sulawesi Province 2016 to 2018. The data analysis technique used in the study uses measurement of effectiveness on budget changes. Based on the calculation result in 2016 of $77 \%$, in 2017 of $56 \%$ and in 2018 of $82 \%$.
\end{abstract}

Key words : Source and Budget Changes

\section{Abstrak}

Penelitian ini bertujuan untuk mengetahui Analisis Sumber dan Perubahan Anggaran pada Badan Pengelola Keuangan Daerah (BPKD) Provinsi Sulawesi Selatan. Jenis penelitian yang digunakan adalah kuantitatif pendekatan deskriptif, data yang diolah adalah perubahan anggaran pada Badan Pengelola Keuangan Daerah (BPKD) Provinsi Sulawesi Selatan tahun 2016 sampai 2018. Teknik analisis data yang digunakan dalam penelitian menggunakan pengukuran efektifitas pada perubahan anggaran. Berdasarkan hasil perhitungan tahun 2016 sebesar 77\%, tahun 2017 sebesar $56 \%$, dan tahun 2018 sebesar $82 \%$

Kata Kunci: Sumber dan perubahan anggaran 


\section{PENDAHULUAN}

Program pembangunan yang telah digariskan oleh pemerintah dapat dilaksanakan secara bertahap dan terencana harus disertai dengan keikutsertaan atau partisipasi dari seluruh instansi pemerintah terkait maupun dari perusahaan swasta serta $m$ asyarakat itu sendiri. Pembangunan Ekonomi dapat terlaksana tidak hanya dengan keikutsertaan Instansi-Instansi pemerintah tetapi serta peran masyarakat.. Perubahan paradigma berpikir diarahkan untuk mengetahui pengelolaan serta kegunaan dari APBN dalam menghasilkan laporan keuangan pemerintah yang transparan dan akuntabilitas yang mendukung peningkatan peran serta masyarakat di bidang keuangan Negara serta meningkatkan kinerja pemerintah, baik pusat ataupun daerah.

Pengelolaan keuangan daerah telah mengalami perubahan yang sangat mendasar sejak diterapkannya otonomi daerah pada tahun 2001. Undang-Undang Pemerintah No.105 Tahun 2000 (sekarang diganti dengan PP. No.58 Tahun 2011), tentang Pengelolaan dan Pertanggungjawaban Keuangan Daerah, dalam ketentuan umumnya menyebutkan bahwa yang dimaksud dengan keuangan daerah adalah semua hak dan kewajiban daerah dalam rangka penyelenggaraan pemerintah daerah yang dapat dinilai dengan uang termasuk didalamnya segala bentuk kekayaan daerah tersebut yang bertujuan menyajikan informasi yang menyangkut posisi keuangan bagi sejumlah pemakai dalam pengambilan keputusan, baik Laporan Keuangan disusun dan disajikan sekurangkurangnya satu tahun sekali untuk memenuhi kebutuhan sejumlah besar pengguna Laporan keuangan merupakan produk akhir dari suatu proses akuntansiAnggaran pada sektor publik terkait dengan proses penentuan jumlah alokasi dana untuk tiap-tiap program dan aktivitas dalam satuan moneter yang menggunakan dana milik rakyat. Hal inilah yang menjadi perbedaan dengan anggaran sektor swasta karena tidak berhubungan dengan pengalokasian dana dari masyarakat. Pada sektor publik pendanaan organisasi berasal dari pajak dan retribusi, laba perusahaan milik daerah atau negara.

Dalam melaksanakan anggaran dan menilai sendiri tentang pencapaian anggaran yang telah di tetapkan maka semakin baik kinerjanya. Anggaran Pendapatan dan Belanja Daerah (APBD) disusun berdasarkan pendekatan kinerja, yaitu suatu sistem anggaran yang mengutamakan upaya pencapaian hasil kerja output dari perencanaan alokasi biaya atau input yang ditetapkan. Anggaran Pendapatan Belanja Daerah (APBD) Tujuannya adalah untuk meningkatkan pelayanan publik dan memajukan perekonomian daerah, serta meningkatkan efisiensi dan efektivitas dalam penyelenggaraan otonomi daerah.

Manganilisis tentang laporan sumber dan perubahan anggaran. laporan itu berguna untuk mengetahui seberapa besar realisasi terhadap anggaran APBN yang telah ditetapkan sebelumnya. Belanja adalah semua pengeluaran dan rekening kas umum Negara/Daerah yang akan mengurangi saldo anggaran lebih dalam periode tahun anggaran yang bersangkutan yang tidak akan diperoleh kembali pembayarannya oleh pemerintah, secara normative. Badan Pengelola Keuangan Daerah (BPKD) merupakan unsur pelaksanaan pemerintah Daerah pada bagian keuangan yang bertugas untuk 
melakukan penegelola keuangan di daerah Sulawesi selatan. Berdasarkan uraian latar belakang masalah di atas, maka penulis tertarik untuk melakukan penyusunan laporan Akhir dengan mengambil judul. "Analisis Sumber Dan Perubahan Anggaran pada Badan Pengelola Keuangan Daerah (BPKD) Provinsi Sulawesi Selatan"

\section{TINJAUAN PUSTAKA}

\section{a. Anggaran}

Anggaran (Budgeting) merupakan alat perencanaan, pedoman, pengendalian dan alat pengawasan di bidang keuangan yang digunakan oleh perusahaan yang berorientasi pada laba maupun non - laba. Bagi suatu perusahaan, penyusunan anggaran merupakan alat yang dipakai untuk membantu aktivitas kegiatannya agar lebih terarah. Dengan menggunakan anggaran maka perkembangan perusahaan / instansi akan dapat dipelajari dengan teliti dan berkesinam bungan.

Anggaran dapat berjalan dengan baik apabila dalam organisasi perusahaan / instansi tersebut ada dukungan aktif, baik dari pelaksanaan tingkat atas maupun tingkat bawah. Hal ini menyangkut kepada manusia, khususnya pada karyawan yang ada pada suatu organisasi dalam melaksanakan kegiatannya. Untuk memahami anggaran, maka pada bab ini akan dibahas mengenai teori yang berhubungan dengan anggaran.

Menurut Munandar (2013:1) Anggaran yaitu suatu rencana yang disusun secara sistematis yang meliputi seluruh kegiatan perusahaan yang dinyatakan dalam unit kesatuan moneter yang berlaku untuk jangka waktu periode tertentu yang akan datang.
Gunawan Adisaputro (2014:02) mendefinisikan Budget adalah suatu pendekatan yang formal dan sistematis dari pelaksanaan tanggung jawab manajemen di dalam perencanaan koordinasi dan pengawasan.

Menurut Nafarin (2014:11), mendefinisikan bahwa Anggaran (budget) merupakan rencana tertulis mengenai kegiatan suatu organisasi yang dinyatakan secara kuantitatif untuk jangka waktu tertentu dan umumnya dinyatakan dalam satuan uang, tetapi dapat juga dinyatakan dalam satuan barang/jasa. Freeman dalam Deddi Nordiawan (2013:19) yang dimaksudkan dengan budget (Anggaran) adalah Anggaran adalah sebuah proses yang dilakukan organisasi sektor publik untuk mengalokasikan sumber daya yang dimilikinya pada kebutuhankebutuhan yang terbatas. Dari definisi di atas, maka dapat diketahui bahwa secara umum anggaran merupakan suatu bentuk rencana aktivitas suatu kegiatan yang akan dilaksanakan selama satu periode mendatang yang secara umum dinyatakan secara kuantitatif berdasarkan angka - angka yang dibuat dengan pertimbangan yang komprehensif.

1) Rencana

Anggaran merupakan suatu rencana yang menggambarkan mengenai kegiatan perusahaan di masa yang akan dating.

2) Mencakup seluruh kegiatan

Anggaran akan dijadikan sebagai pendoman kerja dan juga sebagai sebagai alat kerja serta alat pengendalian, maka anggaran harus dapat mencakup semua kegiatan yang akan dilaksanakan oleh semua bagian yang ada diperusahaan

3) Dinyatakan dalam satuan moneter 
Unit moneter ini sangat dibutuhkan, mengingat bahwa setiap unit masingmasing berbeda seperti misalnya bahan baku menggunakan satuan berat (kg), satuan panjang (m), satuan isi (i), tenaga kerja menggunakan satuan kerja (misalnya harian). Dengan unit moneter dapatlah diseragamkan semua satuan yang berbeda tersebut, sehingga perbedaan antara yang di rencanakan dengan yang direalisasikan memungkinkan untuk dijumlahkan, diperbandingkan serta dianalisa lebih lanjut.

Pada dasarnya bahwa tujuan pokok anggaran adalah memprediksi transaksi dan kejadian finansial serta nonfinansial di masa yang akan datang, dan mengembangkan setiap informasi yang akurat dan bermakna bagi penerima anggaran. Tujuan penyusunan anggaran menurut Nafarin (2014:19), antara lain adalah sebagai berikut :

1) Digunakan sebagai landasan yuridis formal dalam memilih sumber dan investasi dana.

2) Mengadakan pembatasan jumlah dana yang dicari dan digunakan.

3) Untuk merinci jenis sumber dana yang dicari maupun jenis investasi dana, sehingga dapat mempermudah pengawasan.

4) Merasionalkan sumber dan investasi dana agar dapat mencapai hasil yang maksimal.

5) Menyempurnakan rencana yang telah disusun karena dengan anggaran menjadi lebih jelas dan nyata terlihat.

6) Untuk menampung dan menganalisis serta memutuskan setiap usulan yang berkaitan dengan keuangan.

Selain tujuan, anggaran juga memiliki manfaat. Menurut Nafarin
(2014:19), manfaat anggaran adalah sebagai berikut :

1) Semua kegiatan dapat mengarah pada pencapaian tujuan Bersama.

2) Dapat digunakan sebagai alat menilai kelebihan dan kekurangan karyawan.

3) Dapat memotivasi karyawan.

4) Menimbulkan rasa tanggung jawab tertentu pada karyawan.

5) Menghindari pemborosan dan pembayaran yang kurang perlu.

6) Sumber daya seperti tenaga kerja, peralatan dan dana dapat dimanfaatkan seefisien mungkin.

7) Alat pendidikan bagi manajer.

Fungsi Anggaran yaitu sebagai alat manajemen telah berjalan sejak awal perusahaan melaksanakan aktivitasnya, yaitu saat aktivitas benar-benar direncanakan dan perencanaan sudah dinyatakan dalam bentuk uang dan unit yang dikeluarkan. Menurut Munandar (2013:10), fungsi anggaran mempunyai tiga kegunaan pokok yaitu :

1) Anggaran berfungsi sebagai pedoman kerja dan memberikan arah serta sekaligus memberikan target-target yang harus dicapai oleh kegiatankegiatan perusahaan diwaktu yang akan datang.

2) Anggaran berfungsi sebagai alat pengkoordinasian kerja agar semua bagian-bagian yang terdapat dalam perusahaan menunjang, saling bekerja sama dengan baik, untuk menuju kesasaran yang telah ditetapkan.

3) Sebagai alat pengawasan kerja berfungsi juga sebagai tolak ukur, sebagai alat pembanding untuk menilai realisasi kegiatan perusahaan nanti. Dengan membandingkan apa yang tertuang didalam anggaran dengan 
apa yang dicapai oleh realisasi kerja perusahaan, dapat dinilai apakah telah sukses bekerja atau kurang.

Di lain pihak menurut Mulyadi (2016:502), fungsi anggaran terdiri dari enam item yaitu :

1) Anggaran merupakan hasil akhir dari proses rencana kerja

2) Anggaran merupakan cetak biru aktifitas yang akan dilaksanakan perusahaan dimasa yang akan datang.

3) Anggaran berfungsi sebagai alat komunikasi intern yang berhubungan yang menghubungkan berbagai unit organisasi dalam perusahaan dan yang menghubungkan manajer atas dan manajer bawah.

4) Anggaran berfungsi sebagai alat tolak ukur yang dipakai sebagai pembanding hasil operasi sesungguhnya.

5) Anggaran berfungsi sebagai alat pengendalian yang memungkinkan manajemen menunjuk bidang yang kuat dan lemah bagi perusahaan.

6) Anggaran berfungsi sebagai alat untuk mempengaruhi dan memotivasi manajer dan karyawan agar senantiasa bertindak secara efektif dan efisien sesuai dengan tujuan organisasi.

Menurut Deddi Nordiawan, dkk (2013:20) anggaran memiliki fungsi, yaitu:

1) Anggaran sebagai alat perencanaan Dengan adanya anggaran, organisasi tahu apa yang harus dilakukan dan kearah mana kebijakan akan dibuat.

2) Anggaran sebagai alat pengendalianDengan adanya anggaran, organisasi sektor publik dapat menghindari adanya pengeluaran yang terlalu besar (overspending) atau adanya penggunaan dana yang tidak semestinya (misspending).

3) Anggaran sebagai alat kebijakan Melalui anggaran, organisasi sektor publik dapat menentukan arah atau kebijakan tertentu.

4) Anggaran sebagai alat politik Dalam organisasi sektor publik, komitmen pengelola dalam melaksanakan program-program yang telah dijanjikan dapat dilihat melalui anggaran.

5) Anggaran sebagai alat koordinasi dan komunikasi.

Melalui dokumen anggaran yang komprehensif, sebuah bagian, unit kerja, atau departemen yang merupakan sub organisasi dapat mengetahui apa yang harus dilakukan dan juga apa yang akan dilakukan oleh bagian / unit kerja lainnya.

6) Anggaran sebagai alat penilaian kinerja.

Anggaran adalah suatu ukuran yang bisa menjadi patokan apakah suatu bagian / unit kerja telah memenuhi target, baik berupa terlaksananya aktivitas maupun terpenuhinya efisiensi biaya.

7) Anggaran sebagai alat motivasi Anggaran dapat digunakan sebagai alat komunikasi dengan menjadikan nilai- nilai nominal yang tercantum sebagai target pencapaian.

\section{Menurut Standar Akuntasi} Pemerintah (2013:8) paragraph 13 menyebutkan bahwa fungsi Anggaran di lingkungan pemerintah mempunyai pengaruh penting dalam akuntasi dan pelaporan keuangan, antara lain Yaitu:

1) Anggaran merupakan pernyataan kebijakan publik. 
2) Anggaran merupakan target fiskal yang menggambarkan keseimbangan antara belanja, pendapatan, dan pembiayaan yang diinginkan.

3) Anggaran menjadi landasan pengendalian yang memiliki konsekuensi hukum.

4) Anggaran memberi landasan penilaian kinerja pemerintah.

Hasil pelaksanaan anggaran dituangkan dalam laporan keuangan pemerintah sebagai pernyataan pertanggungjawaban pemerintah kepada publik.

Dari pendapat yang dikemukakan di atas dapat Disimpulkan bahwa fungsi anggaran berhubungan erat dengan fungsi perencanaan, pelaksanaan dan pengawasan.

karakteristik Anggaran menurut Mulyadi (2016:490), mengatakan bahwa karakteristik dari anggaran sebagai berikut:

1) Anggaran dinyatakan dalam satuan keuangan dan satuan selain keuangan.

2) Anggaran umumnya mencakup jangka waktu satu tahun.

3) Anggaran berisi komitmen atas kesanggupan manajemen, yang berarti bahwa para manajer setuju unuk menerima tanggung jawab untuk mencapai sasaran yang telah ditetapkan dalam anggaran.

4) Usulan anggaran yang telah dan disetujui oleh pihak yang berwenang lebih tinggi dari penyusunan anggaran.

5) Sekali disetujui, anggaran hanya dapat diubah dibawah kondisi tertentu.

6) Secara berkala, kinerja keuangan sesungguhnya dibandingkan dengan anggaran dan selisihnya dianalisis dan dijelaskan.

7) Menurut Robert \& Vijay (2015:73) anggaran memiliki karakteristikkarakteristik sebagai berikut:

8) Anggaran mengestimasikan potensi laba dari unit bisnis tersebut.

9) Dinyatakan dalam istilah moneter, walaupun jumlah moneter mungkin didukung dengan jumlah non-moneter.

10) Biasanya meliputi waktu selama satu tahun

11) Merupakan komitmen manajemen; menejer setuju untuk menerima tanggung jawab atas pencapaian tujuan - tujuan anggaran.

12) Usulan anggaran ditinjau dan disetujui oleh pejabat yang lebih tinggi wewenangnya dari pembuat anggaran.

13) Setelah disetujui, anggaran hanya dapat diubah dalam kondisi-kondisi tertentu.

14) Secara berkala, kinerja keuangan aktual dibandingkan dengan anggaran, dan varians dianalisis serta dijelaskan

\section{b. Sumber Anggaran}

Menurut Halim (2015: 64), sumber adalah Pendapatan asli daerah merupakan semua penerimaan daerah yang berasal dari sumber ekonomi asli daerah. Menurut Halim (2015: 65), sumber adalah Dana perimbangan merupakan dana yang bersumber dari penerimaan anggaran dana pendapatan dan belanja Negara (APBN) yang dialokasikan kepada daerah untuk membiayai kebutuhan daerah. Menurut Bratakusumah (2013: 173), sumber adalah Pendapatan asli daerah adalah penerimaan yang diperoleh dari sumbersumber dalam wilayahnya sendiri yang dipungut berdasarkan peraturan daerah 
sesuai dengan peraturan perundangundangan yang berlaku.

Dalam rangka melaksanakan penyusunan rumah tangga sendiri pemerintah daerah diberikan kebebasan dalam menghimpun dan seperti diatur dalam pasal 5, 6, dan 7 Undang-undang RI No.33 TAHUN 2004 yang menyatakan bahwa dalam pelaksanaan desentralisasi daerah berhak atas penerimaan daerah yaitu:

1) Pasal 5: (1) Penerimaan daerah dalam pelaksanaan desentralisasi terdiri atas pendapatan daerah dan pembiayaan. Pendapatan daerah sebagaimana maksud pada ayat 1 bersumber dari pendapatan asli daerah dan dan perimbangan.

2) Pasal 6: (1) Pendapatan asli daerah bersumber dari pajak daerah, retribusi daerah, hasil pengelolaan kekayaan daerah yang dipisahkan dan pendapatan daerah yang sah.

Pendapatan asli daerah yang sah sebagaimana dimaksud pada ayat 1 meliputi:

1) Hasil penjualan kekayaan daerah yang tidak dipisahkan

2) Jasa Giro

3) Pendapatan bunga

4) Keuntungan selisih nilai tukar rupiah terhadap mata uang asing

5) Komisi

6) Potongan

\section{c. APBD}

Menurut Yani (2013:369), APBD merupakan rencana keuangan tahunan pemerinthan daerah yang dibahas dan disetujui Bersama oleh pemrintah daerah dan DPRD, dan ditetapkan dengan peraturan daerah. Menurut Yani (2013;369), dalam menyusun terdapat beberapa asas umum yang harus dijadikan pedoman, yaitu sebagai berikut:
1) APBD harus disesuaikan dengan kebutuhan penyelenggaraan pemerintahan dan kemampuan pendapatan daerah.

2) Penyusunan APBD berpedoman kepada Rencana Kerja Pemerintah Daerah (RKPD) dalam rangka mewujudkan pelayanan kepada masyarakat untuk tercapainya tujuan bernegara. RKPD merupakan dokumen perencanaan daerah untuk periode satu tahun.

3) APBD mempunyai fungsi otorisasi, perencanaan, pengawasan, alokasi, distribusi, dan stabilisasi. Fungsi otorisasi mengandung arti bahwa anggaran daerah menjadi dasar untuk melaksanakan pendapatan dan belanja pada tahun yang bersangkutan. Fungsi perencanaan mengandung arti bahwa anggaran daerah menjadi pedoman bagi manajemen dalam merencanakan kegiatan pada tahun yang bersangkutan. Fungsi pengawasan mengandung arti bahwa anggaran daerah menjadi pedoman untuk menilai apakah kegiatan penyelenggaraan pemerintahan daerah sesuai dengan ketentuan yang telah ditetapkan. Fungsi alokasi mengandung arti bahwa anggaran daerah harus diarahkan untuk menciptakan lapangan kerja/mengurangi pengangguran dan pemborosan sumber daya, serta meningkatkan efisiensi dan efektivitas perekonomian. Fungsi distribusi mengandung arti bahwa kebijakan anggaran daerah harus memerhatikan rasa keadilan dan kepatutan. Fungsi stabilisasi mengandung arti bahwa anggaran pemerintah daerah menjadi alat untuk memelihara dan 
mengupayakan keseimbangan fundamental perekonomian daerah.

4) APBD, perubahan APBD, dan pertanggungjawaban pelaksanaan APBD setiap tahun ditetapkan dengan peraturan daerah.

5) Semua penerimaan dan pengeluaran daerah baik dalam bentuk uang, barang dan/atau jasa dianggarkan dalam APBD berdasarkan nilai perolehan atau nilai wajar.

6) Jumlah pendapatan yang dianggarkan dalam APBD merupakan perkiraan yang terukur secara rasional yang dapat dicapai untuk setiap sumber pendapatan.

7) Seluruh pendapatan daerah, belanja daerah, dan pembiayaan daerah dianggarkan secara bruto dalam APBD, yaitu jumlah pendapatan daerah yang dianggarkan tidak boleh dikurangi dengan belanja yang digunakan dalam rangka menghasilkan pendapatan tersebut dan/atau dikurangi dengan bagian pemerintah pusat/daerah lain dalam rangka bagi hasil.

8) Pendapatan daerah yang dianggarkan dalam APBD harus berdasarkan pada ketentuan peraturan perundang-undangan.

9) Dalam menyusun APBD, penganggaran pengeluaran harus didukung dengan adanya kepastian tersedianya penerimaan dalam jumlah yang cukup.

10) Penganggaran untuk setiap pengeluaran APBD harus didukung dengan dasar hukum yang melandasinya.

11) Tahun anggaran APBD meliputi masa satu tahun mulai tanggal 1 januari sampai dengan 31 desember
Pendapatan daerah meliputi semua uang melalui rekening kas umum daerah yang menambah ekuitas dana lancar, serta merupakan hak daerah dalam satu tahun anggaran dan tidak perlu dibayar kembali oleh daerah. Belanja daerah mencakup semua pengeluaran uang dari rekening kas umum daerah yang mengurangi ekuitas dana lancar, dan merupakan kewajiban daerah dalam satu tahun anggaran yang tidak akan diperoleh pembayarannya kembali oleh daerah. Pembiayaan daerah meliputi semua penerimaan uang yang perlu dibayar kembali dan/atau pengeluaran yang akan diterima kembali, baik pada tahun anggaran yang bersangkutan maupun pada tahun-tahun anggaran berikutnya.

\section{d. Anggaran Belanja}

Berdasarkan Pernyataan Standar Akuntansi Pemerintahan (PSAP) Nomor 02 paragraf 8 , pengertian belanja adalah semua pengeluaran dari Rekening Kas Umum Negara/Daerah yamg mengurangi ekuitas dana lancar dalam periode tahun anggaran bersangkutan yang tidak akan diperoleh pembayarannya kembali oleh pemerintah. Menurut Abdul Hafiz Tanjung (2014:103), Belanja dibagi menjadi empat yaitu: Belanja Operasi adalah pengeluaran anggaran untuk kegiatan sehari-hari pemerintah daerah yang memberikan manfaat jangka pendek. Belanja operasi terdiri atas:

1) Belanja pengawai, adalah pengeluaran yang ditetapkan dalam dokumen DPA untuk kompensasi, dalam bentuk gaji dan tunjangan, serta penghasilan lainnya yang diberikan kepada pengawai negeri sipil yang ditetapkan sesuai peraturan perundang-undangan.

2) Belanja barang, adalah pengeluaran yang ditetapkan dalam DPA untuk 
barang-barang pakai habis dan menurut kriteria yang ditetapkan tidak dapat digolongkan sebagai aktiva tetap.

3) Belanja bunga, adalah pengeluaran yang ditetapkan dalam dokumen DPA hutang (principal outstanding) berdasarkan perjanjian pinjaman jangka pendek, jangka menengah, dan jangka panjang yang dilakukan pemerintah daerah kepada pihak ketiga.

4) Belanja subsidi, adalah pengeluaran yang ditetapkan dalam DPA untuk pemberian subsidi kepada badan usaha milik daerah/

\section{METODE PENELITIAN}

Teknik analisis yang digunakan dalam penelitian ini dengan menyajikan angka, table dan uraian penjelasan pengukuran pelaksanaan belanja pendapatan dengan menggunakan pengukuran efektivitas pada perubahan anggaran 2016-2018 pada Badan Pengelola Keuangan Daerah Provinsi Sulawesi Selatan.

1. Pengukuran efektivitas

Rasio Efektivitas = Biaya (Belanja) $x$ $100 \%$

\section{Pendapatan}

2. Kriteria efektivitas
a. $100 \%$ ke atas sangat efektif
b. $90 \%$ sampai $100 \%$ efektif
c. $80 \%$ sampai $90 \%$ cukup efektif
d. $60 \%$ sampai $80 \%$ kurang efektif
e. Kurang dari $60 \%$ tidak efektif

\section{HASIL DAN PEMBAHASAN}

\section{a. Sumber anggaran}

1) Pendapatan asli daerah

Pendapatan Asli Daerah adalah pendapatan yang diperoleh daerah yang dipunggut berdasarkan peraturan sesuai dengan peraturan perundang-undangan yang dalam hal ini adalah UU No 33 Tahun 2004. Pendapatan Asli Daerah bersumber dari pajak daerah, retribusi daerah, hasil pengelolaan kekayaan daerah yang dipisahkan dan lain-lain pendapatan daerah yang sah. Pendapatan Asli Daerah bertujuan memberikan kewenangan kepada pemerintah daerah untuk mendanai pelaksanaan otonomi daerah sesuai dengan potensi daerah sebagai perwujudan desentralisasi.

2) Pajak Daerah

Pajak daerah adalah iuran wajib yang harus dibayar oleh wajib pajak, yang mana dalam pelaksanaannya dijamin dengan ketentuan dalam perundangundangan. Pajak daerah bersumber dari Pajak hotel dan restoran Pajak hiburan, Pajak reklame, Pajak penerangan jalan, Pajak pemanfaatan air dalam tanah dan permukaan, dll.

3) Retribusi daerah

Retribusi daerah merupakan suatu pungutan daerah yang diambil sebagai pembayaran atas jasa terhadap adanya aktivitas pengeluaran dan pemberian perizinan tertentu oleh pemerintah daerah yang diberikan secara khusus untuk pihak tertentu baik pribadi maupun badan usaha

Retribusi daerah dibagi menjadi 3, yaitu retribusi jasa umum digunakan untuk melayani kepentingan umum dan secara menyeluruh dapat meningkatkan kualitas penyediaan jasa agar semakin layak dan memenuhi standard. Retribusi jasa umum bersumber dari retribusi pelayanan kesehatan, retribusi parkir, retribusi pasar

Retribusi jasa usaha bersifat komersial atau mampu mendatang keuntungan dari hasil yang diberikan kepada publik, dimana dalam jenis ini 
terdapat peran pemerintah daerah yang masih tergolong minim, sehingga dibutuhkan peran swasta untuk memaksimalkan bentuk pelayanan kepada masyarakat bersumber dari retribusi transportasi, retribusi kebersihan lingkungan, retribusi tempat penginapan.

4) Retribusi perizinan tertentu Pemberian izin yang bertujuan

untuk melindungi kepentingan umum dan sebagai langkah antisipasi jika terdapat dampak negatif yang ditimbulkan dari adanya pemberian izin tersebut. Bersumber dari retribusi pendirian bangunan, izin gangguan, izin trayek.

5) Hasil pengelolaan kekayaan daerah yang dipisahkan.

Kekayaan negara yang dipisahkan adalah komponen kekayaan negara yang pengelolaannya diserahkan kepada Badan Usaha Milik Negara atau Badan Usaha Milik Daerah. bersumber dari bagian laba dari perusahaan daerah, bagian laba dari lembaga keuangan bank, bagian laba atas penyertaan modal kepada badan usaha lainnya.

6) Lain-Lain Pendapatan yang Sah.

Berdasarkan undang-undang yang berlaku mengenai pemerintah daerah, disana disebutkan jika sumber pendapatan daerah diperoleh dari lainlain pendapatan yang sah. Memang tidak dijelaskan secara spesifik apa saja yang termasuk dalam kategori jenis pendapatan ini. Bersumber dari dana darurat dan hibah yang merupakan penerimaan dari daerah lain, baik itu mencakup provinsi, kabupaten, maupun kota.

7) Pendapatan transfer

Merupakan pendapatan yang berasal dari entitas pelaporan lain, seperti Dana perimbangan, dana transfer umum dan dana transfer khusus, lain-lain pendapatan daerah yang sah

8) Dana bagi hasil

Bersumber dari pajak dan kekayaan, daerah, dimana menurut pasal 11 ayat 1 UU No.33 Tahun 2004, Dana bagi hasil yang bersumber dari pajak terdiri dari Pajak bumi dan bangunan (PBB), Bea perolehan hak atas tanah dan bangunan (BPHTB) dan Pajak penghasilan $(\mathrm{PPH})$

9) Dana alokasi umum

Merupakan komponen tersebesar dalam dana perimbangan dan peranannya sangat strategis dalam menciptakan pemerataan dan keadilan antar daerah. Penggunaan dana alokasi umum ditetapkan oleh daerah. Penggunaan dana alokasi umum dan penerimaan umum lainnya dalam APBD harus tetap pada kerangka pencapaian tujuan pemberian otonomi kepada daerah yaitu peningkatan pelawanan dan kesejahteraan masyarakat yang semakin baik seperti pelayanan di bidang kesehatan dan pendidikan.

Bersumber dari pendapatan APBN yang dialokasikan untuk pemerataan keuangan daerah untuk mendanai kebutuhan daerah dalam rangka pelaksanaan desentralisasi.

10) Dana alokasi khusus

Adalah dana yang bersumber dari pendapatan APBN yang dialokasikan kepada daerah tertentu dengan tujuan membantu mendanai kegiatan khusus yang merupakan urusan daerah dan sesuai dengan prioritas nasional.

\section{b. Perubahan APBD}

Dasar Perubahan APBD, Perubahan APBD dapat dilakukan apabila terjadi:

1) perkembangan yang tidak sesuai dengan asumsi KUA; 
2) keadaan yang menyebabkan harus dilakukan pergeseran anggaran antar unit organisasi, antar kegiatan, dan antar jenis belanja;

3) keadaan yang menyebabkan saldo anggaran Iebih tahun sebelumnya harus digunakan dalam tahun berjalan;

4) keadaan darurat; dan luar biasa.

Tabel 4.1 Ringkasan perubahan anggaran Tahun Anggaran 2016 - 2018

\begin{tabular}{|c|c|c|c|}
\hline TAHUN & URAIAN & $\begin{array}{c}\text { SEBELUM } \\
\text { PERUBAHAN }\end{array}$ & SETELAH PERUBAHAN \\
\hline \multirow[t]{8}{*}{2016} & Pendapatan & $\begin{array}{l}\text { 6.851.571.777.550, } \\
00\end{array}$ & 7.363.500.229.703,00 \\
\hline & $\begin{array}{l}\text { 1. Pendapatan asli } \\
\text { daerah }\end{array}$ & $\begin{array}{l}3.511 .644 .271 .550,0 \\
0\end{array}$ & $3.516 .797 .239 .983,00$ \\
\hline & 2. Pendapatan transfer & $\begin{array}{l}3.328 .111 .729 .000,0 \\
0\end{array}$ & $3.834 .773 .537 .720,00$ \\
\hline & $\begin{array}{l}\text { 3. Lain-lain pendapatan } \\
\text { yang sah }\end{array}$ & $11.815 .777 .000,00$ & $11.929 .452 .000,00$ \\
\hline & Belanja & $\begin{array}{l}5.101 .581 .929 .754, \\
77\end{array}$ & $5.871 .116 .828 .091,15$ \\
\hline & 1. Belanja operasi & $\begin{array}{l}4.207 .954 .369 .665,8 \\
7\end{array}$ & $4.936 .645 .528 .265,12$ \\
\hline & 2. Belanja modal & $868.879 .018 .870,14$ & $931.888 .751 .523,74$ \\
\hline & 3. Belanja tidak terduga & $24.748 .541 .218,76$ & $2.582 .548 .302,29$ \\
\hline 2017 & Pendapatan & $\begin{array}{l}\text { 8.901.928.775.365, } \\
00\end{array}$ & 9.292.958.272.501,00 \\
\hline & $\begin{array}{l}\text { 1. Pendapatan asli } \\
\text { daerah }\end{array}$ & $\begin{array}{l}3.724 .172 .762 .535,0 \\
0\end{array}$ & $3.743 .344 .520 .531,00$ \\
\hline & 2. Pendapatan transfer & $\begin{array}{l}5.166 .208 .141 .000,0 \\
0\end{array}$ & $5.536 .834 .278 .020,00$ \\
\hline & $\begin{array}{l}\text { 3. Lain-lain pendapatan } \\
\text { yang sah }\end{array}$ & $11.547 .871 .830,00$ & $12.779 .473 .950,00$ \\
\hline & Belanja & $\begin{array}{l}7.675 .846 .477 .028, \\
22\end{array}$ & 7.751.147.856.087,96 \\
\hline
\end{tabular}




\begin{tabular}{|c|c|c|c|}
\hline & 1. Belanja operasi & $\begin{array}{l}6.591 .338 .409 .800,5 \\
7\end{array}$ & $6.563 .287 .993 .710,22$ \\
\hline & 2. Belanja modal & $\begin{array}{l}1.059 .508 .067 .227,6 \\
5\end{array}$ & $1.177 .859 .862 .377,74$ \\
\hline & 3. Belanja tidak terduga & $25.000 .000 .000,00$ & $10.000 .000 .000,00$ \\
\hline 2018 & Pendapatan & $\begin{array}{l}\text { 9.482.139.783.434, } \\
00\end{array}$ & 9.539.849.988.329,00 \\
\hline & $\begin{array}{l}\text { 1. Pendapatan asli } \\
\text { daerah }\end{array}$ & $\begin{array}{l}3.917 .732 .579 .914,0 \\
0\end{array}$ & $3.975 .726 .084 .809,00$ \\
\hline & 2. Pendapatan transfer & $\begin{array}{l}5.531 .513 .551 .400,0 \\
0\end{array}$ & $5.531 .513 .551 .400,00$ \\
\hline & $\begin{array}{l}\text { 3. Lain-lain pendapatan } \\
\text { yang sah }\end{array}$ & $32.893 .652 .120,00$ & $32.610 .352 .120,00$ \\
\hline & Belanja & $\begin{array}{l}7.880 .997 .436 .400, \\
60\end{array}$ & 7.849.165.385.870,22 \\
\hline & 1. Belanja operasi & $\begin{array}{l}\text { 6.770.620.032.420,6 } \\
0\end{array}$ & $6.705 .105 .775 .655,88$ \\
\hline & 2. Belanja modal & $\begin{array}{l}1.090 .377 .403 .980,0 \\
0\end{array}$ & $1.140 .259 .610 .214,34$ \\
\hline & 3. Belanja tidak terduga & $20.000 .000 .000,00$ & $3.800 .000 .000,00$ \\
\hline
\end{tabular}

Sumber: Badan Pengelola Keuangan Daerah (BPKD) Privinsi Sulawesi Selatan.

Pendapatan transfer pada tahun 2016 sebelum perubahan sebesar Rp. 3.328.111.729.000,00 dan setelah perubahan sebanyak Rp. 3.829.980.708.720,00 sedangkan pada tahun 2017 pendapatan transfer sebelum perubahan sebesar Rp. 5.166.208.141.000,00 dan setelah perubahan sebanyak Rp. 5.525.650.037.099,00 sedangkan pada tahun 2018 pendapatan transfer sebelum perubahan sebesar
5.531.513.551.400,00 dan setelah perubahan anggarannyatetap tidak mengalami kenaikan maupun penurunan. Pendapatan lain-lain yang sah pada tahun 2016 sebelum perubahan sebesar Rp. 11.815.777.000,00 dan setelah perubahan sebesar Rp11.929.452.000,00 sedangkan pada tahun 2017 lain-lain pendapatan yang sah sebelum perubahan sebesar $\mathrm{Rp}$. 11.547.871.830,00 dan setelah perubahan sebanyak Rp. 12.779.473.950,00 
Sedangkan pada tahun 2018 lain-lain pendapatan yang sah sebelum perubahan sebanyak Rp. 32.893.652.120,00 dan setelah perubahan sebanyak Rp. 32.610.352.120,00.

Belanja operasi pada tahun 2016 sebelum perubahan sebesar Rp. 4.207.954.369.665,87 dan setelah perubahan sebanyak Rp 4.642.852.839.272,31 sedangkan pada tahun 2017 belanja operasi sebelum perubahan sebesar Rp. 6.591.338.409.800,57 dan setelah perubahan sebanyak Rp. 6.119.023.015.392,91 sedangkan pada tahun 2018 belanja operasi sebelum perubahan sebesar Rp. $6,770,620,032,420.60$ dan setelah perubahan sebanyak Rp. 6.705.105.775.655,88.

Belanja modal pada tahun 2016 sebelum perubahan sebesar Rp. 868.879.018.870,14 dan setelah perubahan sebanyak Rp. 930.203.240.523,74 sedangkan pada tahun 2017 Belanja modal sebelum perubahan sebesar Rp. 1.059.508.067.227,65 dan setelah perubahan sebanyak Rp. 1.177.859.908.377,74 sedangakan pada tahun 2018 belanja modal sebelum perubahan sebesar Rp. $1,090,377,403,980.00$ dan setelah perubahan sebanyak Rp. 1.140.259.610.214,34.

Belanja tidak terduga pada tahun 2016 sebelum perubahan sebesar Rp. 24.748.541.218,76 dan setelah perubahan sebanyak Rp. 17.582548.302,29 sedangkan pada tahun 2017 belanja tidak terduga sebelum perubahan sebesar Rp. 25.000.000.000,00 dan setelah perubahan sebanyak Rp. 10.000.000.000,00 sedangkan pada tahun 2018 belanja tidak terduga sebelum perubahan $\mathrm{Rp}$.
20,000,000,000.00 dan setelah perubahan sebanyak Rp. 3.800.000.000,00 Rasio Efektivitas Penggunaan Anggaran (RPA)

Berikut penjelasan Rasio efektifitas penggunaan anggaran pada tabel diatas;

\section{a. Tahun 2016}

Hasil dari rasio efektifitas Badan Pengelola keuangan daerah (BPKD) Tahun Anggaran 2016, biaya belanja sebelum perubahan sebesar Rp. 5.101.581.929.754,77 dan setelah perubahan sebesar Rp. 5.871.116.828.091,15 sedangkan pendapatan sebelum perubahan sebesar Rp. 6.851.571.777.550,00 dan setelah perubahan sebesar Rp. 7.363.500.229.703,00.

Rasio Efektivitas Anggaran

$=$ Biaya (Belanja) $\times 100 \%$ Pendapatan

$$
\begin{aligned}
& =\frac{10.972 .698 .757 .845,92}{14.215 .072 .007 .253,00} \times 100 \% \\
& =77 \%
\end{aligned}
$$

Rasio antara belanja dan pendapatan sebanyak $77,19 \%$ dengan demikian diperoleh rasio efektivitas sebanyak $77 \%$ di kategorikan kurang efektif.

\section{b. Tahun 2017}

Hasil dari rasio efektifitas Badan Pengelola keuangan daerah (BPKD) Tahun Anggaran 2017, biaya belanja sebelum perubahan sebesar Rp. 7.675.846.477.028,22 dan setelah perubahan sebesar Rp. 7.751.147.856.087,96 sedangkan pendapatan sebelum perubahan sebesar Rp. 8.901.928.775.365,00 dan setelah perubahan sebesar Rp. 9.292.958.272.501,00 
Rasio Efektivitas Anggaran

$=$ Biaya (Belanja) $\times 100 \%$

Pendapatan

$=\underline{15.426 .994 .333 .116,18 \times 100 \%}$

$9.831 .887 .047 .866,00$

$=56 \%$

Rasio antara belanja dan pendapatan sebanyak 56,90\% dengan demikian diperoleh rasio efektivitas sebanyak 56\% di kategorikan tidak efektif.

\section{c. Tahun 2018}

Hasil dari rasio efektifitas Badan Pengelola keuangan daerah (BPKD) Tahun Anggaran 2018, biaya belanja sebelum perubahan sebesar Rp. 7.880.997.436.400,60 dan setelah perubahan sebesar Rp. 7.849.165.385.870,22 sedangkan pendapatan sebelum perubahan sebesar Rp 9.482.139.783.434,00 dan setelah perubahan sebesar Rp. 9.539.849.988.329,00

\section{Rasio Efektivitas Anggaran}

$=$ Biaya (Belanja) $\times 100 \%$

Pendapatan

$=\underline{15.730 .162 .822 .270,82} \times 100 \%$

19.021.989.771.763,00

$=82 \%$

Rasio antara belanja dan pendapatan sebanyak 82,69\% dengan demikian diperoleh rasio efektivitas sebanyak $82 \%$ di kategorikan kurang efektif.

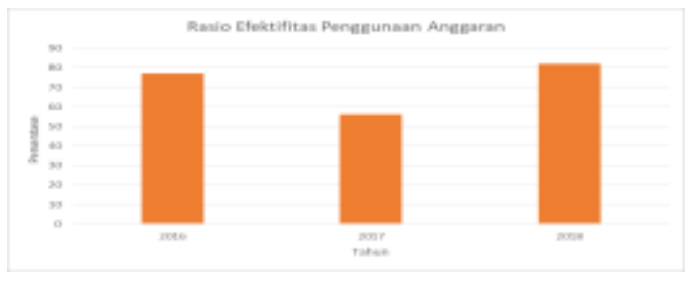

Gambar 4.2 Rasio efektifitas Penggunaan Anggaran Tahun 2016-2018

\section{PENUTUP}

\section{a. Simpulan}

Hasil dari rasio efektifitas Badan Pengelola keuangan daerah (BPKD) Tahun Anggaran 2016, selisih antara belanja dan pendapatan sebanyak $77,19 \%$ dengan demikian diperoleh rasio efektivitas sebanyak $77 \%$ di kategorikan kurang efektif. Hasil dari rasio efektifitas Badan Pengelola keuangan daerah (BPKD) Tahun Anggaran 2017, selisih antara belanja dan pendapatan sebanyak $56,90 \%$ dengan demikian diperoleh rasio efektivitas sebanyak 56\% di kategorikan tidak efektif. Hasil dari rasio efektifitas Badan Pengelola keuangan daerah (BPKD) Tahun Anggaran 2018, selisih antara belanja dan pendapatan sebanyak $82,69 \%$ dengan demikian diperoleh rasio efektivitas sebanyak $82 \%$ di kategorikan kurang efektif.

Realisasi (perubahan) anggaran harusnya disetujui oleh DPRD (Dewan Perwakilan Rakyat Daerah), dan ini menunjukkan bahwa implementasi dan penggunaan anggaran digunakan untuk menjalankan pemerintahan dan pembangunan.

\section{b. Saran}

1. Sumber-sumber anggaran sebaiknya lebih di perhatikan dan optimalisasikan agar pendapatan lebih meningkat daripada tahun-tahun sebelumnya

2. Penyusunan perubahan anggaran Setiap bulan atau paling lama 3 bulan dilakukan evaluasi program atau kegiatan apa saja yang belum dilaksanakan. 


\section{DAFTAR PUSTAKA}

Adisaputro, Gunawan. 2014, Anggaran Perusahaan, Buku I, BPFE Universitas Gajah Mada, Yogyakarta.

Abdul Hafiz tanjung. 2014 Akuntansi, Transparansi, dan Akuntanbilitas Keungan Publik. Yogyakarta: BPFE UGM.

Halim, Abdul, 2015. Auditing (Dasar-dasar Audit Laporan Keuangan). Jilid 1.Edisi Kelima. UPP STIM YKPN: Yogyakarta.

Munandar, M. 2013. Budgeting Perencanaan Kerja Pengkoordinasian Kerja Pengawasan Kerja. Yogyakarta : BPFE.

Mulyadi, 2016.Akuntansi Manajemen .Edisi 3. Jakarta : Salemba Empat.

Peraturan pemerintah no. 71 tahun 2013 tentang standar akuntansi pemerintah

Nafarin, M. 2014. Penganggaran Perusahaan. Jakarta : Salemba Empat.

Nordiawan, Deddi, dkk, 2013, Akuntansi Pemerintahan, Penerbit : Salemba Empat, Jakarta.

Robert, A. dan Govindarajan,Vijay. 2015.Sistem Pengendalian Manajemen. Salemba Empat. Jakarta.

Riyadi, Bratakusumah, 2013, Perencanaan Pembangunan Derah, PT Gramedia Indonesia, Jakarta.

Syafri, Sofyan,Harahap. 2013. Budgeting Perencanaan Lengkap. Jakarta : PT. Gravindo Persada.
Sugiyono, 2013, Metode Penelitian Kuantitatif, Kualitatif dan R \& D, Alfabeta, Bandung.

2015, Cara mudah Menyusun Skripsi, Tesis dan Disertai, Alfabeta, Bandung.

Yani Ahmad, S.H., M.M., AK, 2013, hubungan keuangan antara pemerintah pusat dan daerah di Indonesia, edisi revisi, cetakan kelima, PT. Gravindo Persada, Jakarta. 